Физиология, биохимия, биофизика

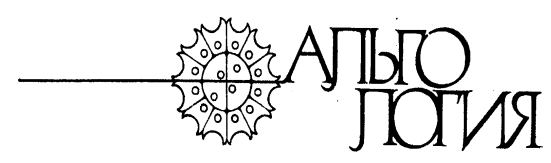

ISSN 0868-854 (Print)

ISSN 2413-5984 (Online). Algologia. 2016, 26(2):137-151

http://dx.doi.org/10.15407/alg26.02.137

УДК 577.342

КОЗЕЛ Н.В., МАНАНКИНА Е.Е., ВЯЗОВ Е.В., ДРЕМУК И.А., САВИНА С.М., АДАМЧИК К.О.

Государственное научное учреждение «Институт биофизики и клеточной инженерии Национальной академии наук Беларуси»,

ул. Академическая, 27, Минск 220072, Беларусь

e-mail: kmu@tut.by

СОСТОЯНИЕ АНТИОКСИДАНТНОЙ СИСТЕМЫ SPIRULINA PLATENSIS (NORDST.) GEITLER В УСЛОВИЯХ СВЕТОДИОДНОГО ОСВЕЩЕНИЯ РАЗНОГО СПЕКТРАЛЬНОГО СОСТАВА

Рассматриваются особенности функционирования антиоксидантной системы Spirulina platensis при выращивании под светодиодными источниками света с разным спектральным составом. Оптимизация спектрального состава источников фотосинтетически активного света весьма актуальна при биотехнологическом производстве хозяйственно ценных видов водорослей, в частности синезеленой водоросли S. platensis. Изучено изменение продуктивности, количества хлорофилла, фикоцианина, каротиноидов, токоферолов, глутатиона, а также активности аскорбатпероксидазы, каталазы и глутатионредуктазы в клетках S. platensis при светодиодном освещении. Установлено снижение антиоксидантного статуса клеток S. platensis при культивировании под светодиодными осветителями с различными комбинациями красного, желтого, голубого и синего светодиодов. Показано, что при использовании в качестве источника фотосинтетически активного света синих светодиодов происходит ингибирование роста $S$. platensis. В условиях избытка красного света, несмотря на существенное (до $30 \%$ ) увеличение продуктивности S. platensis, наблюдается снижение содержания в клетках фикоцианина по отношению к остальным пигментам. Добавление к красному желтого, голубого и синего света позволяет повысить на $17 \%$ продуктивность S. platensis по отношению к белому свету, а также более чем на $15 \%$ увеличить продукцию ценного антиоксиданта фикоцианина. Установлено, что для образцов с повышенной продуктивностью, выращенных под красным, комбинированным красным и синим светом, а также под осветителем, содержащем в своем спектральном составе красный, желтый, голубой и синий свет, характерно снижение количества низкомолекулярного антиоксиданта токоферола, а также активности ключевых антиоксидантных ферментов аскорбатпероксидазы и каталазы, в то время как при использовании только синего света при выращивании $S$. platensis снижается количество восстановленного глутатиона и активность глутатионредуктазы.

Ключевы е слова: Spirulina platensis, антиоксидантная система, фотосинтетически активный свет, спектральный состав, светодиоды.

(c) Козел Н.В., Мананкина Е.Е., Вязов Е.В., Дремук И.А., Савина С.М.,

Адамчик K.O., 2016 


\section{Введение}

Использование светодиодных источников света при выращивании фотосинтезирующих организмов в условиях искусственного освещения представляет большой интерес с точки зрения высокой энергоэффективности таких осветителей и получения оптимального спектрального состава для создания наиболее благоприятных условий для роста и развития растений (Мартиросян и др., 2013). Если энергоэффективность светодиодных источников фотосинтетически активного света полностью определяется конструктивными особенностями самого осветителя, то для получения наиболее оптимального спектрального состава при выращивании фотосинтезирующих организмов необходимо знать и учитывать особенности восприятия света каждым конкретным растительным объектом.

Ранее в экспериментах, проведенных в Институте биофизики и клеточной инженерии НАН Беларуси, по изучению влияния узкополосного излучения красных и синих светодиодов и их совместного действия на динамику окислительных процессов в растениях огурца было показано, что светодиодное освещение с одной спектральной полосой (синей либо красной) оказывает существенное стрессовое воздействие на растительный организм, выражающееся в накоплении активных форм кислорода (АФК), в т. ч. пероксида водорода, а также интенсификации процессов перекисного окисления липидов в листьях огурца (Вязов, Шалыго, 2013). Совместное действие синего и красного узкополосного света также приводило к накоплению в них АФК и деструкции мембран, хотя и в меньшей степени, что указывает на наличие стрессовых условий. Известно, что уровень АФК в растениях контролируется антиоксидантной системой, в состав которой входят низкомолекулярные соединения, из которых наиболее важными для растительной клетки являются токоферол, аскорбат, глутатион и каротиноиды, а также специфические антиоксидантные ферменты, такие как аскорбатпероксидаза (АПО), глутатионредуктаза (ГР), каталаза (КАТ) и супероксиддисмутаза (Arora et al., 2002). Исследование функционирования антиоксидантной системы растительной клетки в условиях светодиодного освещения может дать представление о степени развития окислительного стресса в растениях, а также о характере протекания окислительных процессов и способности растительного организма сопротивляться стрессовому воздействию, что позволит оптимизировать спектральный состав осветителя.

Оптимизация спектрального состава источников фотосинтетически активного света весьма актуальна при биотехнологическом производстве хозяйственно ценных видов водорослей, в частности синезеленой водоросли Spirulina platensis, которая уже около полувека является объектом промышленной биотехнологии для получения биомассы, используемой при лечении и профилактике болезней, в качестве 
витаминно-кормовой добавки к рациону питания сельскохозяйственных животных, для промышленного получения из нее различных ценных веществ - антиоксидантов $\beta$-каротина и фикоцианина, а также полиненасыщенных жирных кислот (Мельников, 2005). Отличительной особенностью фотосинтетического аппарата $S$. platensis по отношению к высшим растениям и некоторым другим видам водорослей является отсутствие в составе фотосинтетических пигментов хлорофилла $b$, a также наличие большого количества фикобилинового пигмента фикоцианина, характерного для синезеленых водорослей, который может активно участвовать не только в процессах светосбора, но и защиты клетки от окислительного воздействия. Указанные особенности могут существенно влиять на адаптацию $S$. platensis к изменению спектрального состава фотосинтетически активного света.

Целью исследования стало изучение особенностей функционирования антиоксидантной системы $S$. platensis, в частности изменения количества фикоцианина, каротиноидов, токоферолов, глутатиона, а также активности АПО, КАТ и ГР в клетках водорослей при выращивании $S$. platensis под светодиодными источниками света с разным спектральным составом.

\section{Материалы и методы}

Для исследования использовали трихомную синезеленую водоросль (цианобактерию) Spirulina (Arthrospira) platensis (штамм IBCE S-2 из коллекции Института биофизики и клеточной инженерии НАН Беларуси) (Мельников и др., 2011). Водоросли выращивали на среде Заррука (Cheevadhanarak et al., 2012) в стеклянных колбах объемом 200 мл (рабочий объем 100 мл) в режиме 14 ч света-10 ч темноты при температуре $25 \pm 2{ }^{\circ} \mathrm{C}$ в течение 7 дней. Количество внесенного посевного материала -300 мг/л. Для изучения влияния светодиодного освещения на продуктивность $S$. platensis и состояние ее антиоксидантной системы использовали культуру в логарифмической фазе роста (на 7-е сутки после пересева). Для выращивания $S$. platensis использовали светодиодный осветитель, сконструированный в Институте биофизики и клеточной инженерии НАН Беларуси (Доманский, Козел, 2013), с различными комбинациями синего (450-465 нм), голубого (465485 нм), желтого (590-595 нм) и красного (630-650 нм) светодиодов (потребляемая мощность одного светодиода около 1 Вт), а также люминесцентную лампу Philips PL-S $11 \mathrm{~W} \backslash 827 \backslash 2 \mathrm{P}$ с потребляемой мощностью 11 Вт, цветовой температурой $2700 \mathrm{~K}$ и светоотдачей 64 Лм/Вт в качестве контроля. Интенсивности световых потоков лампы и светодиодного осветителя изначально были выравнены по энергии и составляли 5 мВт/см ${ }^{2}$.

Продуктивность Spirulina platensis определяли по изменению биомассы, которую оценивали по поглощению и светорассеянию суспензии при 560 нм на спектрофотометре Metertech SP-830 Plus 
(Тайвань) (Sasaki et al., 1995). Определение фикоцианина в биомассе $S$. platensis проводили спектрофотометрически согласно методике, описанной в работе (Sasaki et al., 1995). Для определения содержания хлорофилла, каротиноидов и токоферолов использовали высокоэффективную жидкостную хроматографию (ВЭЖХ). Хлорофилл и каротиноиды экстрагировали из клеток S. platensis $90 \%$-ным ацетоном и хроматографировали, используя колонку Nucleodur C18 Gravity (тип C18, размер частиц 3 мкм, длина 15 см) фирмы Macherey-Nagel (Германия) и хроматограф Shimadzu Prominence LC 20 (Япония). Содержание хлорофилла и каротиноидов определяли спектрофотометрически, используя детектор с диодной матрицей SPD-M20A (Shimadzu, Япония) (Rodriguez-Amaya et al., 2004). Токоферолы экстрагировали из клеток $S$. platensis 100 \%-ным этанолом и хроматографировали, используя колонку Nucleodur C18 Gravity (тип C18, размер частиц 5 мкм, длина 25 см, Macherey-Nagel, Германия). Содержание $\alpha$ - и $\gamma$-токоферола определяли по флуоресценции при длине волны возбуждающего света 295 нм и длине волны регистрации 325 нм, применяя флуоресцентный детектор RF-20AXS (Shimadzu, Япония) (Tanaka et al., 1999). В качестве стандартов использовали коммерческие препараты фирмы «Sigma». Окисленный (GSSG) и восстановленный (GSH) глутатион определяли спектрофлуориметрическим методом (Hissin, Hilf, 1976), модифицированным в Институте биофизики и клеточной инженерии НАН Беларуси (Шалыго и др., 2007).

Активность АПО определяли по кинетике потребления аскорбата, регистрируя изменение оптической плотности при 290 нм в течение 2 мин $\left(\varepsilon=2,8 \mathrm{mM}^{-1} \mathrm{~cm}^{-1}\right)$ (Nakano, Asada, 1981), активность KAT - по кинетике потребления пероксида водорода, которую регистрировали при 240 нм в течение 5 мин $\left(\varepsilon=39,6 \mathrm{M}^{-1} \mathrm{~cm}^{-1}\right)$ (Rios-Gonzales et al., 2002), активность ГР - по кинетике потребления НАДФН, регистрируя уменьшение оптической плотности при 340 нм в течение 5 мин $(\varepsilon=$ 6,2 $\mathrm{мM}^{-1} \mathrm{~cm}^{-1}$ ) (Gechev et al., 2002). Активность АПО, КАТ и ГР измеряли на спектрофотометре Uvikon 931 фирмы Kontron (Германия). Bce данные представлены как средние арифметические и их стандартные отклонения, вычисленные из трех независимых опытов. Статистические данные обрабатывали с помощью программы «SigmaPlot 12.5». Различия считали статистически достоверными при $p<0,05$.

\section{Результаты и обсуждение}

Для выращивания S. platensis мы использовали светодиоды с полосами испускания в красной и синей областях спектра. Попытка использовать именно такие светодиоды для культивирования водорослей не случайна, так как в фотосинтезирующих организмах в качестве основных пигментов-светосборщиков выступают хлорофилл и каротиноиды, которые наиболее эффективно поглощают свет в указанной области 
спектра. Именно этими критериями руководствуется большинство исследователей, применяя для выращивания растений в разных комбинациях только синие и красные светодиоды и исключая из спектра излучения зеленый свет (Мартиросян и др., 2013). Также для выращивания $S$. platensis, содержащей большое количество фикоцианина и $\beta$-каротина, кроме классических красного и синего светодиодов и их комбинации (красный:синий - 2:1 по энергии излучения) мы применяли осветитель более сложной конструкции, в спектре излучения которого содержался дополнительно желтый и голубой свет (красный:желтый:голубой:синий - 3:3:1:1 по энергии излучения).

Изменение продуктивности, содержания фикоцианина и каротиноидов у Spirulina platensis при выращивании под светодиодными осветителями и люминесцентной лампой Philips (контроль)

\begin{tabular}{|c|c|c|c|c|c|c|}
\hline \multirow{2}{*}{ Свет } & \multirow{2}{*}{$\begin{array}{c}\text { Продук- } \\
\text { тив- } \\
\text { ность, } \\
\text { мг/л }\end{array}$} & $\begin{array}{c}\text { Фико- } \\
\text { цианин }\end{array}$ & $\begin{array}{l}\text { Хлоро- } \\
\text { филл } a\end{array}$ & $\beta$-каротин & $\begin{array}{c}\text { Виолаксан- } \\
\text { тин } \\
\end{array}$ & Лютеин \\
\hline & & \multicolumn{3}{|c|}{ мг/г с.б. } & \multicolumn{2}{|c|}{ мКг/г с.б. } \\
\hline $\begin{array}{l}\text { Белый } \\
\text { (люм. } \\
\text { лампа } \\
\text { Philips) }\end{array}$ & $\begin{array}{c}595,8 \pm \\
34,3\end{array}$ & $57,4 \pm 8,6$ & $17,6 \pm 0,8$ & $4,3 \pm 0,32$ & $225,3 \pm 19,2$ & $840,0 \pm 81,9$ \\
\hline Красный & $\begin{array}{c}782,2 \pm \\
40,0^{*} \\
\end{array}$ & $55,7 \pm 7,2$ & $18,8 \pm 0,5^{*}$ & $4,7 \pm 0,17^{*}$ & $213,3 \pm 8,8$ & $970,0 \pm 35,1^{*}$ \\
\hline Синий & $\begin{array}{c}322,8 \pm \\
12,5^{*}\end{array}$ & $\begin{array}{l}69,7 \pm \\
11,4^{*} \\
\end{array}$ & $17,6 \pm 0,2$ & $4,1 \pm 0,01^{*}$ & $\begin{array}{c}300,0 \pm \\
17,3^{*}\end{array}$ & $876,7 \pm 28,5$ \\
\hline $\begin{array}{l}\text { Красный } \\
+ \text { синий } \\
(2: 1)\end{array}$ & $\begin{array}{c}715,1 \pm \\
19,7^{*}\end{array}$ & $56,5 \pm 7,3$ & $19,0 \pm 1,0^{*}$ & $4,8 \pm 0,29 *$ & $\begin{array}{c}256,7 \pm \\
23,3^{*}\end{array}$ & $996,7 \pm 91,2^{*}$ \\
\hline $\begin{array}{l}\text { Красный } \\
+ \text { желтый } \\
+ \\
\text { голубой } \\
+ \text { синий } \\
\text { (3:3:1:1) }\end{array}$ & $\begin{array}{c}696,4 \pm \\
21,6^{*}\end{array}$ & $65,9 \pm 3,1^{*}$ & $16,1 \pm 0,9^{*}$ & $3,9 \pm 0,26^{*}$ & $204,2 \pm 21,0$ & $748,7 \pm 27,5^{*}$ \\
\hline
\end{tabular}

Пр и м ечан и е. Здесь и далее г с.б. - грамм сухой биомассы, * - различия по сравнению с контролем достоверны, $p<0,05$.

Все использованные в работе варианты светодиодного освещения, за исключением синего, позволили добиться на 17-31\% более высокой продуктивности $S$. platensis по сравнению с контрольным вариантом, выращенным под люминесцентной лампой (см. таблицу). При 
использовании только синего света мы наблюдали двукратное уменьшение продуктивности водорослей, основной причиной которого может быть снижение фотосинтетической активности клеток S. platensis в связи с отсутствием в спектральном составе освещения желтого и красного света, наиболее эффективно поглощаемого фикоцианином (максимум поглощения фикоцианина - 620 нм).

Анализ ацетоновых экстрактов суспензии S. platensis методом ВЭЖХ позволил выявить в исследуемых препаратах наличие каротиноидов виолаксантина, лютеина и $\beta$-каротина, а также хлорофилла $a$. На рис. 1 представлена типичная для исследованных препаратов хроматограмма ацетонового экстракта из суспензии S. platensis с ярко выраженными пиками виолаксантина, лютеина, хлорофилла $a$ и $\beta$-каротина.

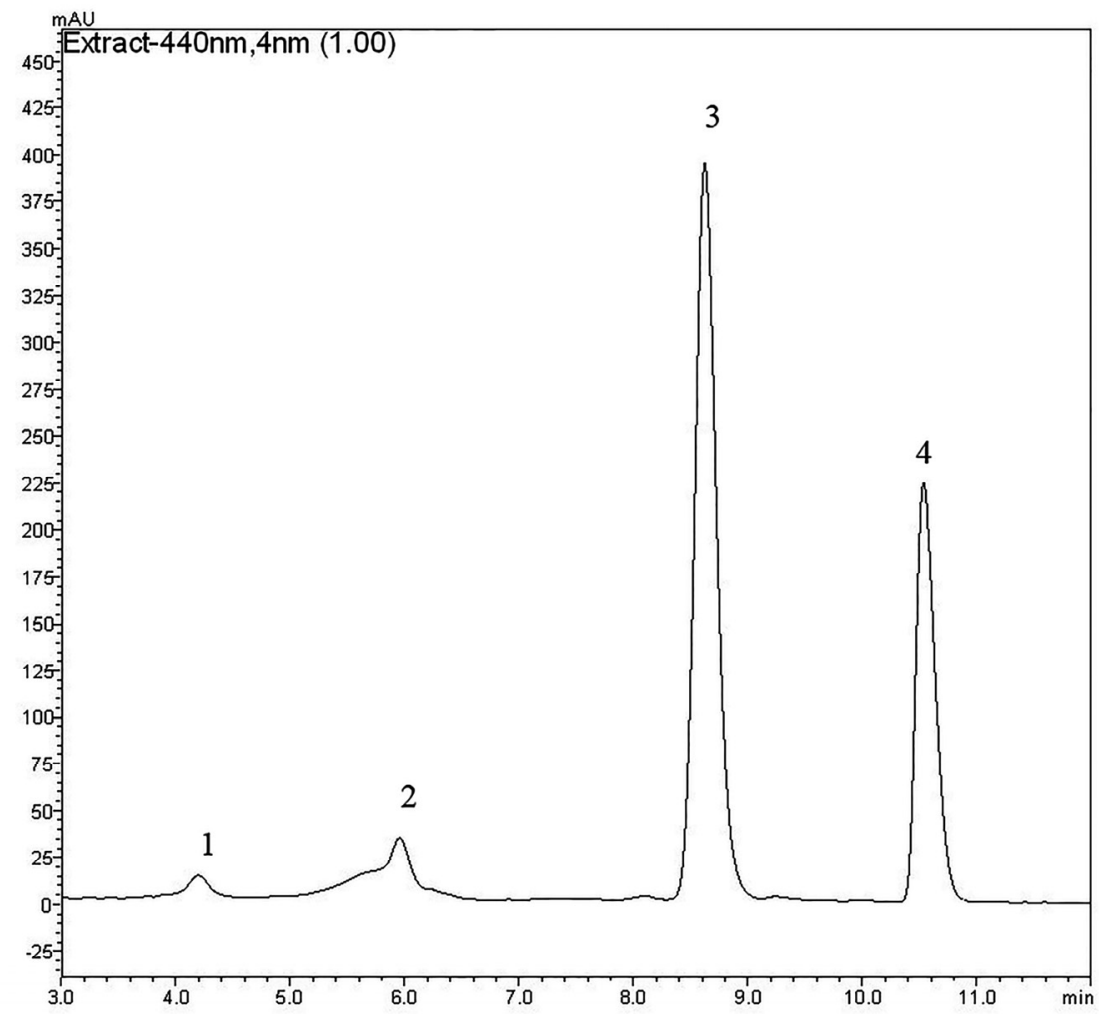

Рис. 1. Хроматограмма экстракта пигментов суспензии Spirulina platensis. Пик № 1 виолаксантин (время удержания 4,20 мин), пик № 2 - лютеин (5,95 мин), пик № 3 - хлорофилл $a$ ( 8,62 мин), пик № $4-\beta$-каротин (10,53 мин)

Избыток красного света в спектре источника света (варианты с использованием красного и совместно красного и синего светодиодов) приводит к повышенному накоплению в клетках S. platensis лютеина на 16 и $19 \%$ для красного и совместно красного и синего света 
соответственно, а также $\beta$-каротина (на 9 и $12 \%$ ) на фоне увеличения содержания хлорофилла $a$ (на 7 и $8 \%$ ) по отношению к контролю (см. таблицу). При этом в варианте с использованием дополнительно желтого и голубого света, наоборот, зафиксировано снижение количества хлорофилла $a$ на $8 \%$, лютеина на $11 \%, \beta$-каротина на $9 \%$, а также виолаксантина на $9 \%$ на фоне увеличения (на $15 \%$ ) содержания в клетках $S$. platensis фикоцианина по отношению к контролю. Отметим существенное возрастание содержания в клетках водорослей на $21 \%$ фикоцианина и на $33 \%$ виолаксантина (который также играет важную роль в светосборе), при выращивании $S$. platensis под синим светом, что может быть связано с активацией в клетке регуляторных механизмов, направленных на интенсификацию фотосинтетических процессов. В целом, такое разнонаправленное изменение содержания каротиноидов и фикоцианина при изменении спектрального состава фотосинтетически активного света, видимо, связано не с участием этих антиоксидантных компонентов в защитных процессах в клетках водорослей, а с адаптацией фотосинтетического аппарата S. platensis к новым условиям освещения.

Методом ВЭЖХ в клетках $S$. platensis идентифицированы $\alpha$ - и $\gamma$ токоферолы, $\alpha$-токоферола ацетат, а также следы $\delta$-токоферола. На рис. 2 представлена типичная хроматограмма спиртового экстракта из суспензии $S$. platensis с пиками $\delta$-токоферола, $\gamma$-токоферола, $\alpha$ токоферола и $\alpha$-токоферола ацетата.

Анализ изменения количества токоферолов в зависимости от спектрального состава светодиодного освещения выявил снижение содержания как $\alpha$ - (рис. $3, A$ ), так и $\gamma$-токоферолов (рис. 3, Б) в образцах, выращенных под красным, комбинированным красным и синим светом, а также под осветителем, содержащем в своем спектральном составе красный, желтый, голубой и синий свет.

Известно, что токоферолы активно участвуют в тушении синглетного молекулярного кислорода как по физическому, так и по химическому механизму (Kim et al, 2006). Синглетный молекулярный кислород образуется в растительной клетке при сильном фотоокислительном стрессе непосредственно в фотосинтетических мембранах. Причиной инициации генерации этой АФК может быть нарушение биосинтеза фотосинтетических пигментов под действием ксенобиотиков либо нарушение переноса электрона в фотосинтетической мембране в результате действия света достаточно высокой интенсивности или тех же ксенобиотиков. Снижение количества токоферолов в указанных образцах может быть связано с развитием фотоокислительного стресса при облучении суспензии водорослей высокими дозами света, наиболее эффективно поглощаемого светособирающими пигментами (Доманский, Козел, 2013). Повышенное содержание токоферолов в варианте с использованием только синих светодиодов (рис. 3, вар. 3), т. е. при отсутствии в спектральном составе 
освещения желтого и красного света, наиболее эффективно поглощаемого фикоцианином, подтверждает это предположение.

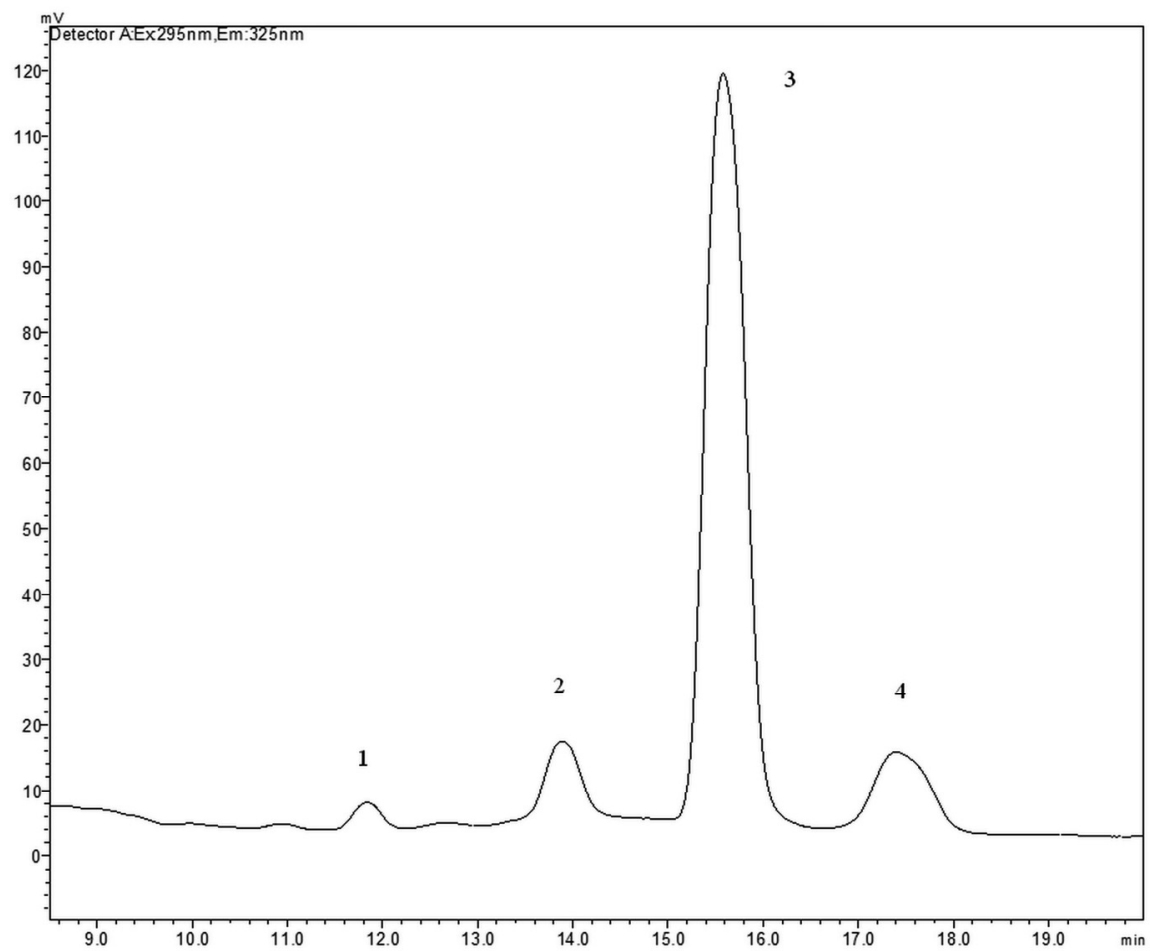

Рис. 2. Хроматограмма спиртового экстракта суспензии Spirulina platensis. Пик № 1 $\delta$-токоферол (время удержания 11,75 мин), пик № $2-\gamma$-токоферол (13,8 мин), пик № $3-\alpha$-токоферол (15,5 мин), пик № $4-\alpha$-токоферола ацетат (17,3 мин)

Также было выявлено существенное снижение активности ключевых защитных ферментов, участвующих в детоксикации перекиси водорода в клетке - АПО и КАТ, которое коррелировало со снижением количества токоферолов в клетках Spirulina platensis при светодиодном освещении красным, красным и синим, а также красным, желтым, голубым и синим светом. Так, активность АПО снижалась по отношению к контролю (белый свет) более чем на $40 \%$ при выращивании $S$. platensis под красным светом и примерно на $25 \%$ при использовании одновременно красного и синего либо красного, желтого, голубого и синего светодиодов (рис. 4, A). Активность КАТ в варианте с красным светом снижалась еще больше - на $63 \%$ по отношению к контролю (рис. 4, Б). Такое существенное снижение активности важных антиоксидантных ферментов может стать лимитирующим фактором, определяющим устойчивость $S$. platensis к стрессовым воздействиям, поэтому использование источника света высокой интенсивности только с красными светодиодами потенциально

\section{4}


опасно, так как может привести к гибели культуры. В варианте с использованием синего света активность АПО была выше контроля на $32 \%$, а активность КАТ снижалась относительно контроля несущественно (в пределах погрешности эксперимента).
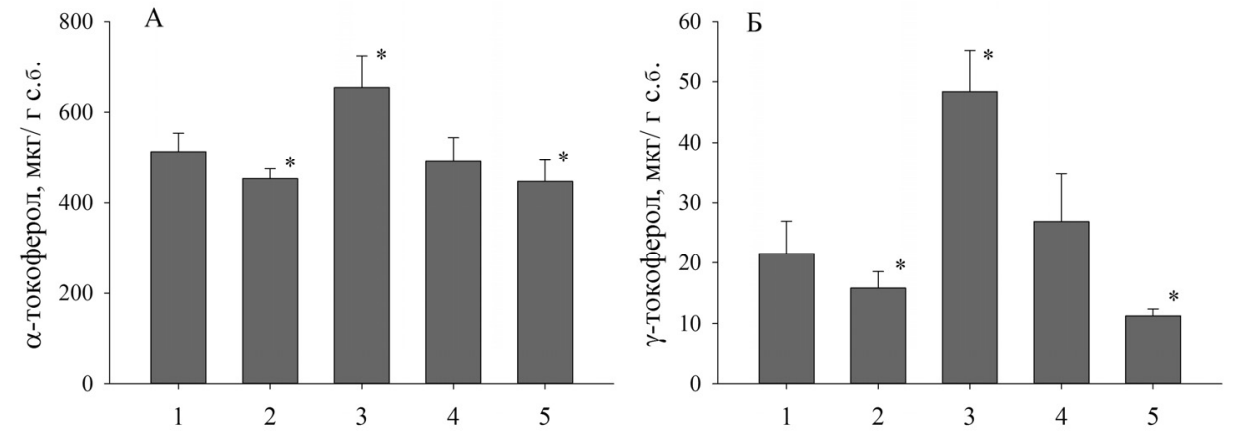

Рис. 3. Содержание $\alpha$ - $(A)$ и $\gamma$-токоферолов (Б) в клетках Spirulina platensis при выращивании под светодиодными осветителями и люминесцентной лампой Philips (контроль). Здесь и далее: 1 - белый (люм. лампа Philips), 2 - красный, 3 - синий, $4-$ красный + синий $(2: 1), 5-$ красный + желтый + голубой + синий $(3: 3: 1: 1)$. * - Здесь и на рис. 4-6 различия по сравнению с контролем достоверны, $p<0,05$
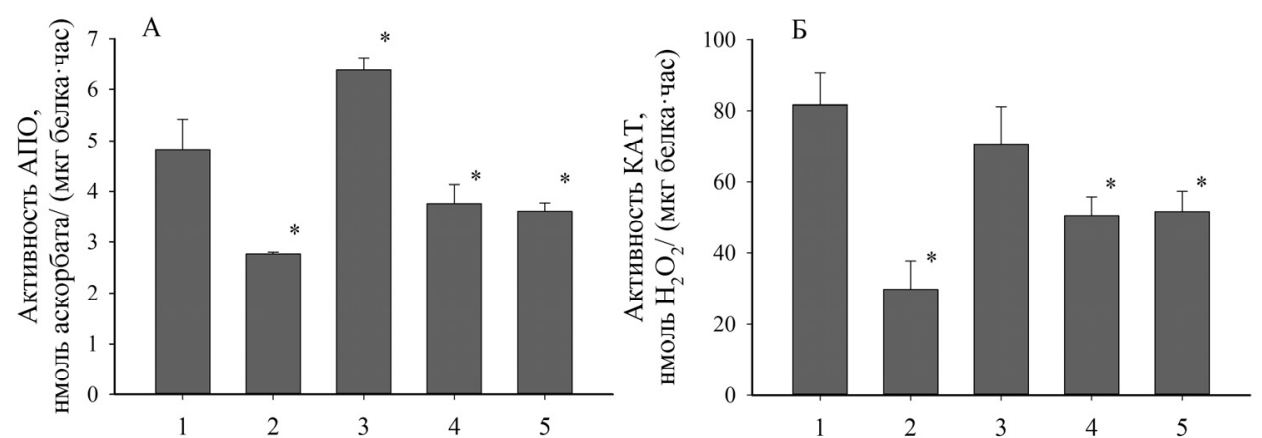

Рис. 4. Активности АПО $(A)$ и КАТ (Б) в клетках Spirulina platensis при выращивании под светодиодными осветителями и люминесцентной лампой Philips (контроль)

Анализ количества глутатиона в клетках S. platensis показал, что соотношение восстановленного и окисленного глутатиона существенно отличается от контроля только в варианте с использованием синего света (рис. 5, B). В этом варианте наблюдается снижение (на $33 \%$ по отношению к контролю) количества восстановленного глутатиона (рис. 5, A) и повышенное накопление (на $42 \%$ по отношению к контролю) его физиологически неактивной окисленной формы (рис. 5,5 ). 


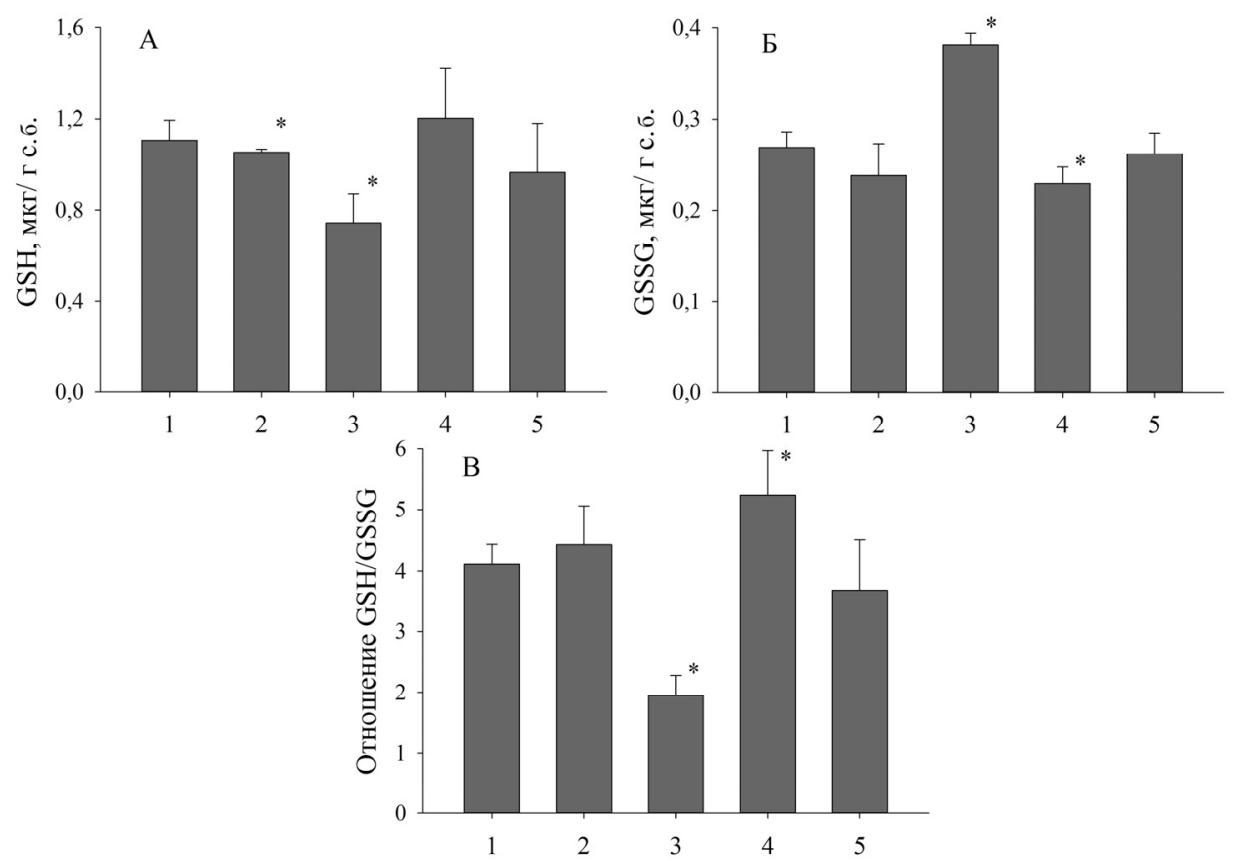

Рис. 5. Содержание восстановленного (A) и окисленного (Б) глутатиона, а также отношение GSH/GSSG в клетках Spirulina platensis при выращивании под светодиодными осветителями и люминесцентной лампой Philips (контроль)

В варианте с использованием совместно синего и красного света (рис. 5, вар. 4), наоборот, количество восстановленного глутатиона было несколько выше контроля (на $9 \%$ ), а окисленного - ниже на $14 \%$, что указывает на активацию антиоксидантной системы в клетках $S$. platensis при таком воздействии. Однако это также указывает на наличие некоторого стрессового воздействия.

Среди компонентов антиоксидантной системы растительной клетки глутатион играет важную роль. Его биологическая функция заключается

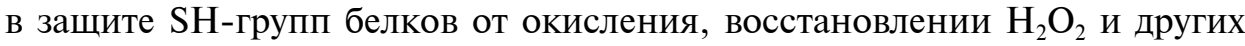
пероксидов, связывании свободных радикалов, а также поддержании пула восстановленного аскорбата. Однако при фотоокислительном стрессе, когда в клетках генерируется синглетный молекулярный кислород, глутатион не является основным защитным компонентом, так как в отличие от токоферолов и каротиноидов менее эффективен при тушении синглетного молекулярного кислорода, с чем, видимо, и связано отсутствие корреляции между изменением количества глутатиона и токоферолов в наших экспериментах.

ГР - фермент, восстанавливающий дисульфидную связь окисленного глутатиона до его физиологически активной сульфгидрильной формы и, соответственно, поддерживающий необходимое для 
нормального функционирования антиоксидантной системы содержание в клетке восстановленного глутатиона. Анализ активности ГР в клетках S. platensis позволил выявить существенное снижение (на $43 \%$ по отношению к контролю) активности этого фермента в варианте с использованием синего света (рис. 6, вар. 3), что объясняет накопление окисленного глутатиона и снижение количества восстановленного в этом варианте.

Рис. 6. Активность глутатион-

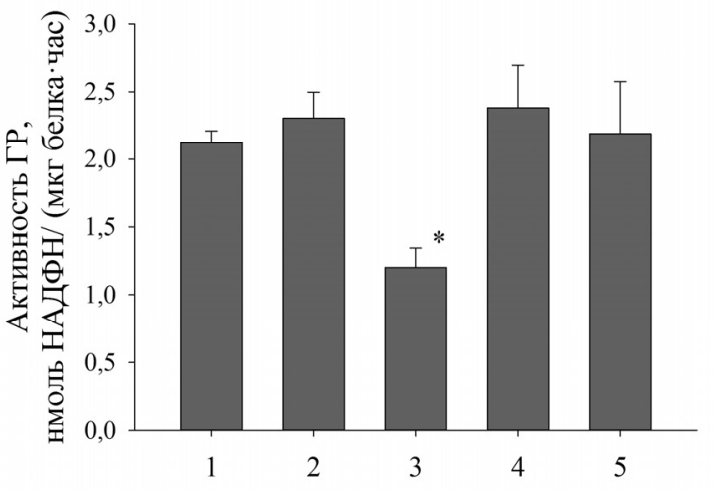

Также известно, что для восстановления окисленной формы глутатиона в фотосинтезирующих организмах используется НАДФН, образующийся при фотосинтезе (Asada, 2000). Но, как было отмечено выше, при использовании только синего света для выращивания S. platensis в клетках водорослей, видимо, происходит снижение фотосинтетической активности в связи с отсутствием в спектральном составе освещения света, поглощаемого фикоцианином, что также может влиять на эффективность восстановления глутатиона. В варианте с использованием совместно красного и синего света активность ГР была самой высокой - на $12 \%$ выше контроля, что согласуется с результатами анализа количества восстановленного и окисленного глутатиона и может указывать на наличие некоторого стрессового воздействия на клетки Spirulina platensis при таком освещении.

\section{Заключение}

При использовании в качестве источника фотосинтетически активного света синих светодиодов происходит ингибирование роста Spirulina platensis, основной причиной которого является снижение фотосинтетической активности клеток $S$. platensis в связи с отсутствием в спектральном составе освещения желтого и красного света, наиболее эффективно поглощаемого фикоцианином.

В условиях избытка красного света, несмотря на существенное (до $30 \%)$ увеличение продуктивности $S$. platensis, наблюдается снижение содержания в клетках фикоцианина по отношению к остальным 
пигментам. Добавление в спектр испускания осветителя дополнительно к красному желтого, голубого и синего света позволяет повысить на $17 \%$ продуктивность S. platensis по отношению к белому свету, а также более чем на $15 \%$ увеличить продукцию ценного антиоксиданта фикоцианина.

Для образцов с повышенной продуктивностью, выращенных под красным, комбинированным красным и синим светом, а также под осветителем, содержащем в своем спектральном составе красный, желтый, голубой и синий свет, характерно снижение количества низкомолекулярного антиоксиданта токоферола, а также активности ключевых антиоксидантных ферментов АПО и КАТ, в то время как использование только синего света для выращивания S. platensis вызывает снижение количества восстановленного глутатиона и активности ГР.

\section{СПИСОК ЛИТЕРАТУРЫ}

Вязов E.B., Шалыго Н.В. Содержание активных форм кислорода, продуктов перекисного окисления липидов и проницаемость клеточных мембран в растениях огурца (Cucumis sativus) в условиях узкополосного освещения // Весці НАН Беларусі. Сер. біял. навук. - 2013. - (2). - С. 71-74.

Доманский В.П., Козел Н.В. Особенности выращивания Spirulina platensis при использовании светодиодных источников света // Весці НАН Беларусі. Сер. біял. навук. - 2013. - (3). - С. 56-59.

Мартиросян Ю.Ц., Полякова М.Н., Диловарова Т.А., Кособрюхов А.А. Фотосинтез и продуктивность растений картофеля в условиях различного спектрального облучения // Сельхоз. биол. - 2013. - (1). - С. 107-112.

Мельников С.С. Спирулина: Справочное пособие в вопросах и ответах. - Минск: Право и экономика, 2005. - 57 с.

Мельников С.С., Мананкина Е.Е., Будакова Е.А., Шалыго Н.В. Каталог генетического фонда хозяйственно полезных видов водорослей. - Минск: Беларус. навука, 2011. - 101 c.

Шалыго Н.В., Щербаков Р.А., Доманская И.Н., Радюк М.С. Спектрофлуориметрический метод определения окисленного и восстановленного глутатиона в растениях // Физиол. и биохим. культ. раст. - 2007. - 39(3). - С. 264-270.

Arora A., Sairam R.K., Srivastava G.C. Oxidative stress and antioxidative system in plants // Curr. Sci. - 2002. - 82(10). - P. 1227-1238.

Asada $K$. The water-water cycle as alternative photon and electron sinks // Philos. Trans. Roy. Soc. Lond. B: Biol. Sci. - 2000. - 355(1402). - P. 1419-1431.

Cheevadhanarak S., Paithoonrangsarid K., Prommeenate P. et al. Draft genome sequence of Arthrospira platensis C1 (PCC9438) // Stand. Genom. Sci. - 2012. - 6(1). - P. 43-53.

Gechev T., Gadjev I., Van Breusegem F., Inzŭ D., Dukiandjiev S., Toneva V., Minkov I. Hydrogen peroxide protects tobacco from oxidative stress by inducing a set of antioxidant enzymes // Cell. Mol. Life Sci. - 2002. - 59(4). - P. 708-714. 
Hissin P.J., Hilf R. A fluorometric method for determination of oxidized and reduced glutathione in tissues // Anal. Biochem. - 1976. - 74(1). - P. 214-226.

Kim H.J., Lee M.Y., Min D.B. Singlet oxygen oxidation rates of $\alpha-, \gamma-$, and $\delta$-tocopherols $/ /$ J. Food Sci. - 2006. - 71(8). - P. 465-468.

Nakano Y., Asada K. Hydrogen peroxide is scavenged by ascorbate-specific peroxidase in spinach chloroplasts // Plant Cell Physiol. - 1981. - 22(5). - P. 867-880.

Rios-Gonzales K., Erdei L., Lips S.H. The activity of antioxidant enzymes in maize and sunflower seedlings as affected by salinity and different nitrogen sources // Plant Sci. 2002. - 162(6). - P. 923-930.

Rodriguez-Amaya D.B., Kimura M. HarvestPlus Handbook for Carotenoid Analysis. Washington: HarvestPlus, 2004. - 63 p.

Sasaki K., Marquez F., Nishio N., Nagai S. Promotive effect of 5-aminolevulinic acid on the growth and photosynthesis of Spirulina platensis // J. Ferment. and Bioeng. - 1995. 79(5). - P. 453-457.

Tanaka R., Oster U., Kruse E., Rudiger W., Grimm B. Reduced activity of geranylgeranyl reductase leads to loss of chlorophyll and tocopherol and to partially geranylgeranylated chlorophyll in transgenic Tobacco plants expressing antisense RNA for geranylgeranyl reductase // Plant Physiol. - 1999. - 120(3). - P. 695-704.

Поступила 7 декабря 2015 г. Подписал в печать А.И. Божков

\section{REFERENCES}

Arora A., Sairam R.K., and Srivastava G.C., Current Sci., 2002, 82(10):1227-1238.

Asada K., Philos. Trans. Roy. Soc. Lond. B: Biol. Sci., 2000, 355(1402):1419-1431.

Cheevadhanarak S., Paithoonrangsarid K., Prommeenate P. et al., Stand. Genom. Sci., 2012, 6(1):43-53.

Domanskii V.P. and Kozel N.V., Vesci NAN Belarusi. Ser. biyal. navuk, 2013, (3):56-59.

Gechev T., Gadjev I., Van Breusegem F., Inzé D., Dukiandjiev S., Toneva V., and Minkov I., Cell. Mol. Life Sci., 2002, 59(4):708-714.

Hissin P.J. and Hilf R., Anal. Biochem., 1976, 74(1):214-226.

Kim H.J., Lee M.Y., and Min D.B., J. Food Sci., 2006, 71(8):465-468.

Martirosyan Yu.Ts., Polyakova M.N., Dilovarova T.A., and Kosobryukhov A.A., Sel'khoz. biol., 2013, (1):107-112.

Melnikov S.S., Spirulina: Spravochnoe posobie v voprosah $i$ otvetah [Spirulina. Handbook: questions and answers], Pravo i ekonomika Publ., Minsk, 2005. (In Rus.)

Melnikov S.S., Manankina E.E., Budakova E.A., and Shalygo N.V., Katalog geneticheskogo fonda hozyajstvenno poleznyh vidov vodoroslej [Catalog of the genetic stock of economically useful of algae species], Belarus. Navuka Publ., Minsk, 2011. (In Rus.)

Nakano Y. and Asada K., Plant Cell Physiol., 1981, 22(5):867-880.

Rios-Gonzales K., Erdei L., and Lips S.H., Plant Sci., 2002, 162(6):923-930. 
Rodriguez-Amaya D.B. and Kimura M., HarvestPlus Handbook for Carotenoid Analysis, HarvestPlus, Washington, 2004.

Sasaki K., Marquez F., Nishio N., and Nagai S., J. Ferment. and Bioeng., 1995, 79(5):453457.

Shalygo N.V., Sherbakov R.A., Domanskaya I.N., and Radyuk M.S., Fiziol. i biohim. kult. rast., 2007, 39(3):264-270.

Tanaka R., Oster U., Kruse E., Rudiger W., and Grimm B., Plant Physiol., 1999, 120(3):695-704.

Viazau Y.V. and Shalygo N.V., Vesci NAN Belarusi, Ser. biyal. navuk, 2013, (2):71-74.

\author{
ISSN 0868-854 (Print) \\ ISSN 2413-5984 (Online). Algologia. 2016, 26(2):137-151 \\ http://dx.doi.org/10.15407/alg26.02.137
}

Kozel N.V., Manankina E.E., Viazau Y.V., Dremuk I.A., Savina S.M., Adamchyk K.O.

State Scientific Institute of Biophysics and Cell Engineering of NAS of Belarus,

27, Academicheskaya St., Minsk 220072, Belarus

\title{
ANTIOXIDANT SYSTEM OF SPIRULINA PLATENSIS (NORDST.) GEITLER UNDER THE LED LIGHTING OF DIFFERENT SPECTRAL COMPOSITIONS
}

Optimization of the spectral composition of photosynthetically active light sources is highly relevant in the biotechnological production of commercially valuable species of algae, particularly blue-green algae Spirulina platensis. The aim of the research was to study the functioning of the antioxidant system of $S$. platensis algae cultivated under LED light sources with different spectral composition. Analysis of changes of productivity, as well as chlorophyll, phycocyanin, carotenoids, tocopherols, glutathione amounts and activity of ascorbate peroxidase, catalase and glutathione reductase in the cells of $S$. platensis grown under LED lighting has been done. The effect of LED lighting with different spectral composition on the state of the main components of the antioxidant system of $S$. platensis has been studied. Reduction of the antioxidant status of cells of the $S$. platensis algae cultivated under LED illumination with various combinations of red, yellow and blue LEDs is revealed. It is shown that, when using blue LEDs as a source of photosynthetically active light the growth of $S$. platensis is inhibited. It is revealed that under the conditions of an excess of red light in spite of the substantial (by $30 \%$ ) increase in the productivity of $S$. platensis, decrease in phycocyanin content in cells in relation to other pigments takes place. Application of an illuminator with yellow and two blue spectral bands in addition to the red light leads to increase in the productivity of $S$. platensis by $17 \%$ compared to white light, as well as increase in production of valuable antioxidant phycocyanin in algae cells by more than $15 \%$. It was found that the samples with increased productivity, grown under the red, combined red and blue light, and under illuminator emitting red, yellow and two types of blue light, had decreased amount of low-molecular antioxidant tocopherol, as well as lower activities of antioxidant enzymes ascorbate peroxidase and catalase, while application 
only blue light for growing $S$. platensis causes a decrease in the amount of reduced glutathione and activity of the glutathione reductase.

Ke y words: Spirulina platensis, antioxidant system, photosynthetically active light, the spectral composition of the LEDs.

\section{NEW BOOKS}

Guidelines for quality control of the Black Sea. Microphytobenthos / Nevrova E.L., Snigireva A.A., Petrov A.N., Kovaleva G.V. / Ed. A.V. Gaevskaya. - Sevastopol; Simferopol: N. Orianda, 2015. - 176 p.

A guideline for quality control of the marine microphytobenthos consists of methodical recommendations for sampling, treatment, laboratory processing and different kinds of analysis of the Black Sea benthic microalgae. It is recommended to apply the indication capabilities of microphytes for assessment the environmental stressors impact upon quantitative indices, distribution pattern and taxonomic structure of taxocenes. Application of different structural indices and non-parametric methods including taxonomic distinctness indices (TaxDI) for assessment of biodiversity features and condition of main components of microphytobenthic assemblages in different environment had discussed. The Annexes are comprised of the list of references using for taxonomical identification of species, algorithms for approximation the shape of cells by geometric figures, formulas and correction factors for calculation of volume and surface area of unicellular microalgae and, besides the checklist of microphytobenthos (Cyanobacteria, Ochrophyta, Dinophyta, Cryptophyta, Haptophyta, Bigyra, Euglenpzoa, Protozoa Incertae Sedis, Chlorophyta), and updated list of benthic diatoms (Bacillariophyta) from north-western part of the Black Sea.

The guidelines is designated for hydrobiologists, ecologists, botanists, experts in ecological monitoring and wild-life conservation, and for university lecturers and students of biological specialties. 
